\title{
Pengaruh Jumlah Uang Beredar, Ekspor Dan Impor Terhadap Inflasi (Studi Empiris Pada Perekonomian Indonesia)
}

\author{
Jumhur $^{*}$ \\ Fakultas Ekonomi dan Bisnis, Universitas Tanjungpura, Pontianak, Indonesia \\ M. Ali Nasrun \\ Memet Agustiar \\ Wahyudi \\ Fakultas Ekonomi dan Bisnis, Universitas Tanjungpura, Pontianak, Indonesia
}

\begin{abstract}
This research aims to analyze the influence of money supply, export, and import on inflation rate in Indonesia. It employs multiple regression method to analyze a time series data between 1985 and 2016. The findings showed that money supply positively and significantly influences inflation rate; export positively and significantly influences inflation rate; and import positively influences inflation yet not significantly. These findings illustrate that Indonesia inflation is also caused by both internal (money supply) and external factors (export and import). Therefore, a policy to stabilize inflation rate shall be formulated by considering both internal and external influences.
\end{abstract}

Keyword: export, import, inflation rate, money supply

\section{PENDAHULUAN}

Inflasi mencerminkan terjadinya penurunan daya beli per unit uang terhadap barang dan jasa dalam perekonomian. Hal ini bisa disebabkan oleh kebijakan moeneter yang ekspansioner berupa penambahan jumlah uang berdedar di masyarakat. Namun, pertumbuhan pasokan jumlah uang beredar tidak selalu menyebabkan inflasi (Ofori, Danquah, \& Zhang, 2017). Pandangan tentang faktor-faktor yang menentukan tingkat inflasi hingga saat ini masih bervariasi. Namun, para ahli memiliki konsensus bahwa periode inflasi yang panjang disebabkan terutama oleh penambahan pasokan jumlah uang beredar yang lebih cepat dibandingkan tingkat pertumbuhan ekonomi (Ofori et al., 2017) . Pasokan uang beredar yang terus meningkat akan menyebabkan harga barang

\footnotetext{
*Email : jumhurie@yahoo.com

Received : 08-08-2018, Accepted : 04-09-2018, Published : 30-12-2018

P-ISSN : 2087-9954, E-ISSN : 2550-0066. DOI : http://dx.doi.org/10.26418/jebik.v7i3.26991
} 
dan jasa meningkat, terutama jika pertumbuhan output telah mencapai kapasitas penuh (Bello \& Saulawa, 2013). Mengingat belum adanya kesimpulan yang komprehensif dari para ahli ekonomi mengenai pengaruh jumlah uang beredar terhadap inflasi, maka pengkajian lebih lanjut mengenai pengaruh jumlah uang beredar terhadap inflasi masih menarik untuk dilakukan.

Dalam ekonomi terbuka, inflasi juga dipengaruhi oleh situasi perdagangan internasional yaitu kondisi impor dan ekspor. Globalisasi ekonomi telah meningkatkan konektivitas dan interdependensi pasar dan bisnis dengan menghapus pembatasan dan hambatan pada pertukaran produk (Ramzan, Fatima, \& ZareenYousaf, 2013) . Ekspor adalah salah satu kegiatan ekonomi andalan penduduk dunia yang berkontribusi terhadap pertumbuhan ekonomi. Peningkatan ekspor juga memberikan jaminan stabilitas ekonomi keuangan suatu negara. Namun, peningkatan ekspor seperti yang dikatakan oleh Bashir et al., (2011) dan Shah, Aleem, \& Nousheen, (2014) tidak hanya bermanfaat bagi ekonomi tetapi juga bisa meningkatkan tekanan inflasi dalam perekonomian karena adanya peningkatan permintaan agregat. Studi tentang hubungan ekspor dengan inflasi telah banyak dilakukan di banyak negara di seluruh dunia seperti yang dilakukan (Shah et al., 2014; Venkadasalam, 2015). Namun sampai saat ini masih ditemukan hasil yang beragam karena kurangnya informasi tentang pengaruh ekspor domestik dan re-ekspor terhadap inflasi sebagai komponen total dari ekspor. Akibatnya belum diperleh kesimpulan yang komprehensif tentang hubungan antara ekspor dan inflasi. Oleh karena itu, penelitian ini akan meneliti hubungan antara ekspor dan inflasi di Indonesia untuk menjembatani kesenjangan ketidakkonsistenan hasil penelitian yang telah ada tentang hubungan antara ekspor dan inflasi.

Impor dapat mempengaruhi inflasi domestik secara langsung melalui harga impor, dan secara tidak langsung melalui persaingan dengan barang dan jasa domestik (Dexter, Levi, \& Nault, 2005). Impor diperlukan untuk mengatasi kenaikan permintaan dalam negeri dengan memanfaatkan kebijakan impor. Namun ketika permintaan telah berada di bawah tingkat output domestik, inflasi akan mulai turun. Biasanya, kenaikan impor akan menyebabkan depresiasi dalam nilai tukar. Ini cenderung meningkatkan tekanan inflasi melalui membuat impor mahal. Selain itu, ketika suatu negara mengimpor bahan mentah maka depresiasi mata uang lokal atau apresiasi mata uang asing membuat impor mahal dan kemudian biaya produksi untuk barang meningkat karena kenaikan harga bahan mentah.

Perekonomian Indonesia sedang menghadapi tren inflasi yang relatif stabil selama bertahun-tahun. Untuk menjaga kesetabilan inflasi yang rendah, perlu untuk memperhatikan dampak dan konsekuensi dari faktor penyebab inflasi seperti jumlah uang beredar, ekspor dan impor. Hasil penelitian ini dapat digunakan dalam proses perumusan kebijakan anti-inflasi dengan mempertimbangkan pengaruh variabel tersebut agar pertumbuhan ekonomi tetap stabil. Berdasarkan penjelasan diatas tentang faktor yang memengaruhi tingkat inflasi di Idonesia, maka penelitian ini akan menguji dan 
menganalisis pengaruh jumlah uang beredar, ekspor dan impor terhadap inflasi di Indonesia tahun 1985-2016.

Artikel ini selanjutnya pada bagian 2 menyajikan kalian liteatur, pada bagian 3 menyajikan metodologi penelitian yang digunakan pada bagian 4 menyajikan hasil penelitian dan pembahasan, dan pada bagian 5 menyajikan kesimpulan.

\section{KALIAN LITERATUR}

\subsection{Tinjauan Teoritis}

Inflasi adalah masalah ekonomi yang tak terelakkan dihampir semua perekonomian dunia. Menurut Greenidge \& Dacosta, (2009) inflasi telah menjadi isu topikal sejak awal 1970-an ketika harga minyak mencatat angka tinggi. Sejak saat itu, mengendalikan tingkat inflasi telah menjadi prioritas utama banyak negara terutama yang memiliki ekonomi terbuka kecil (Greenidge \& Dacosta, 2009). Inflasi berarti kenaikan harga umum secara terus menerus dalam ekonomi dan menimbulkan ancaman serius terhadap stabilitas ekonomi makro di seluruh dunia (Bashir et al., 2011). Friedman dan Schwartz (1970) dalam (Tafti, 2012), menulis sebuah buku yang berpengaruh pada sejarah moneter Amerika Serikat mengatakan bahwa inflasi selalu ada dan di mana-mana merupakan fenomena moneter.

Ekonom dari berbagai aliran pemikiran telah mempresentasikan teori mereka mengenai penyebab inflasi. Pada inflasi era Keynesian diyakini disebabkan oleh peningkatan permintaan agregat yaitu inflasi tarikkan permintaan atau penurunan penawaran agregat yaitu inflasi dorongan biaya. Para ekonom di era ini menganggap kebijakan fiskal sebagai mekanisme penting untuk mengendalikan inflasi. Model Phillips Curve dikembangkan oleh Phillips, (1958) menyajikan gagasan trade-off antara inflasi dan pengangguran. Model ini menunjukkan hubungan negatif antara inflasi dan pengangguran. Model teori kuantitas uang mengatakan bahwa pasokan uang memiliki hubungan langsung dan proporsional dengan tingkat harga. Ini menekankan peran kebijakan moneter terhadap kebijakan fiskal dalam mengendalikan inflasi.

Menurut Friedman, (1969) dalam (Tafti, 2012) sebagai Aliran Monetaris berpendapat bahwa inflasi dalam negeri disebabkan oleh kelebihan jumlah uang beredar dalam perekonomian. Monetaris menyoroti defisit anggaran pemerintah merupakan faktor penting yang berkontribusi terhadap inflasi. Ini terjadi karena dengan adanya defisit anggaran, pemerintah merasa perlu untuk meminjam atau mencetak lebih banyak uang untuk pengeluarannya. Hal ini kemudian menyebabkan lebih banyak uang dalam sirkulasi perekonomian sehingga mengakibatkan inflasi (Ogbokor, 2004). Strukturalis berpendapat bahwa inflasi disebabkan oleh tekanan permintaan faktor struktural dan tekanan biaya. Hal ini dapat menyebabkan perubahan harga di dunia nyata dari harga uang seperti upah. Upah cenderung tidak fleksibel ke bawah; ini dapat menyebabkan inflasi (Ogbokor, 2004). Para strukturalis lebih lanjut menyatakan bahwa perubahan 
dalam struktur ekonomi menyebabkan harga relatif naik. Ini mengarah pada pengaruh harga uang, dengan kata lain mengarah pada pertumbuhan jumlah uang beredar.

Pada perekonomian terbuka inflasi juga dipengaruhi oleh situasi perdagangan internasional yaitu kondisi impor dan ekspor. Menurut Dexter et al., (2002) ketersediaan impor dapat mempengaruhi inflasi domestik secara langsung melalui harga impor. dan secara tidak langsung melalui persaingan dengan barang dan jasa domestik. Sedangkan ekspor mempengaruhi persediaan produk yang tersedia bagi konsumen domestic sehingga kesetabilan harga bisa terjaga.

\subsection{Tinjauan Empiris}

\subsubsection{Pengaruh Jumlah Uang Beredar Terhadap Inflasi}

Banyak studi empiris tentang pengaruh jumlah uang beredar terhadap inflasi telah dilakukan, meskipun dengan hasil yang bervariasi. Bozkurt, 2014) menganalisis hubungan uang, inflasi, dan pertumbuhan ekonomi di Turki menggunakan uji kointegrasi, menganalisis data persediaan uang triwulanan $\left(\mathrm{M}_{2}\right)$, Pruduk Domestik Bruto, perputaran uang dan deflator tahun 1999Q1-2012Q4 menemukan bahwa penambahan jumlah uang beredar merupakan penentu utama inflasi dalam jangka panjang di Turki. (Koyuncu, 2014) menggunakan data time-series guna menguji pengaruh jumlah uang beredar pada inflasi pada periode 1987-2013 terjadi hubungan kausalitas dari jumlah uang beredar ke inflasi di Turki. Tang \& Lein, (2007) menganalisis hubungan antara jumlah uang beredar $\left(\mathrm{M}_{1}\right)$ dan inflasi di Malaysia menemukan bahwa jumlah uang beredar $\left(\mathrm{M}_{1}\right)$ berdampak negatif dan signifikan secara statistik terhadap inflasi di Malaysia. Implikasi dari penelitian ini adalah tidak mendukung pandangan monetaris yang menunjukkan bahwa inflasi murni merupakan fenomena moneter. Studi Inam, (2014) meneliti hubungan kausal jangka panjang antara pasokan jumlah uang beredar dan inflasi di Nigeria periode 1970-2011 menggunakan teknik regresi co-integrasi multivariat, menemukan ada hubungan linear jangka panjang antara suplai uang dan inflasi di Nigeria. Berdasarkan hasil tinjauan riset mengenai pengaruh jumlah uang beredar dengan inflasi yang masih beragam penelitian berupaya memberikan komprehensif mengenai hubungan antara jumlah uang beredar dengan inflasi di Indonesia.

\subsubsection{Pengaruh Ekspor terhadap Inflasi}

Akinbobola, (2012) bertujuan untuk menyediakan analisis kuantitatif dari dinamika jumlah uang beredar, nilai tukar dan inflasi di Nigeria. mengganakan data kuartalan dari 1986: 01 hingga 2008: 04. Menggunakan Vector Error Correction Mechanism (VECM). Hasil empiris menegaskan bahwa dalam jangka panjang, jumlah uang beredar dan nilai tukar memiliki pengaruh terbalik yang signifikan terhadap tekanan inflasi, ada hubungan kausal antara inflasi, jumlah uang beredar dan nilai tukar di Nigeria. (Jaradat, 2013) meneliti faktor-faktor yang mempengaruhi inflasi di Yordania menggunakan data kuartalan dari tahun 2000 hingga kuartal ketiga tahun 2010 dengan menerapkan konsep 
kointegrasi, Hasil penelitian menunjukkan ekspor memiliki hubungan jangka panjang yang positif dengan inflasi. di Yordania. Rehman \& Khan, (2015) meneliti faktor-faktor yang mempengaruhi inflasi harga makanan di Pakistan selama tahun 1990-2013 menggunakan model Vector Error Correction dan uji intergrasi Johansen menemukan bahwa ekspor pangan memiliki pengaruh jangka panjang yang positif dan signifikan terhadap inflasi harga makanan di Pakistan. Dengan cara yang sama, Arif \& Ali, (2012) menganalisis determinan utama inflasi di Bangladesh menggunakan data untuk periode 1978 - 2010. Temuan berdasarkan koefisien korelasi menunjukkan hubungan negatif yang lemah antara ekspor dan inflasi.

Tinjauan studi empiris tentang hubungan ekspor dan inflasi menggambarkan kurangnya konsensus tentang hubungan antara ekspor dan inflasi sehingga mengahasilkan hasil yang masih beragam. Kemudian mayoritas studi berfokus pada total ekspor tanpa melibatkan komponen-komponen ekspor domestik dan re-ekspor yang membuat pengaruhnya terhadap inflasi tidak diketahui. Oleh karena itu penelitian berupaya memberikan analisis yang komprehensif untuk menganalaisis hubungan antara ekspor dan inflasi.

\subsubsection{Pengaruh Impor terhadap Inflasi}

Sejumlah studi berfokus pada hubungan dinamis inflasi dengan impor. Ulke \& Ergun, (2012) dengan menggunakan data seri waktu bulanan untuk ekonomi Turki selama periode 1995-2010, menunjukkan bahwa ada hubungan jangka panjang dan dinamis antara inflasi dan impor. Sebuah kausalitas searah dari impor ke inflasi juga ditemukan dalam penelitian itu. Abidemi, Maliq, \& Ago-Iwoye, (2010) menganalisis hubungan dinamis dan simultan antara inflasi dan determinannya di Nigeria, menggunakan teknik kointegrasi Johansen dan model koreksi kesalahan untuk menganalisis determinan inflasi untuk data periode 1970-2007 menemukan bahwa variabel impor memiliki hubungan positif dengan inflasi. Ogbokor, (2004) menguji apakah inflasi di Namibia didorong oleh impor. Menggunakan metode Ordinary Least Square untuk menganalisis data tahun 1990- 2007 menemukan inflasi di Namibia sangat bergantung pada impor. Selanjutnya Islam, (2013) melakukan studi empiris tentang dampak impor terhadap inflasi, menggunakan data tahun 2008-2012 menemukan bahwa ada korelasi sangat kecil antara inflasi dan impor.

Berdasarkan hasil tinjauan riset sebelumnya tentang pengaruh Impor terhadap inflasi yang masih beragam penelitian berupaya memberikan analisis yang komprehensif untuk mengkaji pengaruh impor terhadap inflasi di Indonesia. 


\section{METODA PENELITIAN}

\subsection{Jenis Dan Sumber Data}

Penelitian ini dilakukan di Indonesia, menggunakan data time series periode 19852016. Semua data dalam penelitian ini diperoleh dari publikasi resmi Badan Pusat Statistik (BPS), Badan Perencanaan Pembangunan Nasional (BAPPENAS), Bank Indonesia (BI) dan instansi lain yang ada kaitannya dengan penelitian ini. Penelitian ini menggunakan metode estimasi Ordinary Least Square (OLS) untuk menguji hubungan antara Inflasi dan faktor yang mempengaruhinya yaitu Jumlah Uang Beredar (JUB) yang diproksi dengan jumlah uang beredar $\mathbf{M}_{2}$, Ekspor yang diproksi dengan semua nilai barang dan jasa lain yang dipasok ke seluruh dunia serta Impor yang diproksi dengan nilai dari semua barang dan jasa lain yang diterima dari berbagai belahan dunia. Karena penelitian ini menggunakan data rentang waktu, maka perlu dilakukan beberapa pengujian yaitu:

\subsubsection{Uji Stasioneritas Data}

Penelitian ini menggunakan data time series, maka pada tahap awal akan dilakukan uji Akar Unit dengan menggunakan Augmented Dickey Fuller (ADF) test untuk mengetahui apakah data time series yang digunakan tersebut, stationer atau tidak. Prosedur untuk mengetahui data stasioner atau tidak dengan membandingkan antara nilai statistik ADF atau PP dengan nilai kritis distribusi Mac Kinnon. Nilai statistik ADF atau PP ditunjukkan oleh nilai t statistik. Jika nilai absolut statistik ADF atau PP lebih besar dari nilai kritisnya, maka data yang diamati menunjukkan stasioner dan jika sebaliknya nilai statistik ADF atau PP lebih kecil dari nilai kritisnya maka data tidak stasioner.

Model persamaannya sebagai berikut:

$\Delta Y_{t}=a_{0}+\gamma Y_{t-1}+\sum_{i=1}^{z}+\beta \Delta Y_{t-1}+1+e t$

Keterangan :

$\mathrm{Y} \quad=$ variabel yang diamati

$\Delta \mathrm{Y}_{\mathrm{t}}=\mathrm{Y}_{\mathrm{t}}-\mathrm{Y}_{\mathrm{t}-1}$

$\mathrm{T} \quad=$ Trend waktu

\subsubsection{Uji Normalitas Data}

Uji normalitas diperlukan untuk menguji apakah dalam model regresi, variabel dependen dan variabel independen mempunyai distribusi normal atau tidak. Salah satu cara untuk mengetahui apakah data penelitian berdistribusi normal atau tidak dapat melihat normal probability plots. Pengujian ini dilakukan dengan cara melihat titik-titik penyebaran data terhadap garis diagonal pada grafik. Kriteria pengambilan keputusan analisis normal probability plots adalah sebagai berikut: 
a. Apabila data yang dapat dilihat dari titik-titik pada grafik menyebar dan mengikuti garis diagonal, maka dapat disimpulkan bahwa data mengikuti pola distribusi normal.

b. Apabila data yang dapat dilihat dari titik-titik pada grafik menyebar dan cenderung menjauh dari garis diagonal serta tidak mengikuti agar garis diagonal, maka dapat disimpulkan data tidak menunjukkan pola distribusi normal.

\subsubsection{Uji mulikoliniaritas}

Salah satu cara untuk mendeteksi gejala multikolinearitas adalah dengan melihat nilai tolerance value atau Variance Inflation Factor $(V I F)$ dengan kriteria keputusan sebagai berikut:

a. Apabila tolerance value $>0.1$ dan $V I F<10$, maka dapat disimpulkan tidak terjadi gejala multikolinearitas antar variabel independent pada model regresi.

b. Apabila tolerance value $<0.1$ dan $V I F>10$, maka dapat disimpulkan terjadi gejala multikolinearitas antar variabel independent pada model regresi.

\subsubsection{Uji Aotokorelasi}

Untuk mendeteksi gejala autokorelasi digunakan uji statistik Durbin-Watson dengan kriteria pengambilan keputusan sebagai berikut:

Apabila dw $<\mathrm{dl}$, maka terjadi autokorelasi negatif

Apabila $\mathrm{dl}<\mathrm{dw}<\mathrm{du}$, maka tidak dapat disimpulkan

Apabila du $<\mathrm{dw}<4-\mathrm{du}$, maka tidak terjadi autokorelasi negatif dan positif

Apabila 4-du > dw < 4-dl, maka tidak dapat disimpulkan

Apabila 4-dl $<$ dw, maka terjadi autokorelasi positif

\subsubsection{Uji Heteroskedastisitas}

Uji Heteroskedastisitas bertujuan untuk mengetahui apakah dalam model regresi terjadi ketidaksamaan variance dari residual satu pengamatan ke pengamatan lain. Model regresi yang baik harus memiliki variance yang sama (homoskedastisitas). Untuk menguji terjadi atau tidaknya gejala heteroskedastisitas dapat menggunakan grafik plot antara nilai prediksi variabel terikat (ZPRED) dengan residualnya (SRESID) dengan dasar keputusan sebagai berikut:

a. Jika pada grafik scatter plot terlihat titik-titik yang membentuk pola tertentu, yang teratur, misal bergelombang, melebar kemudian menyempit, maka dapat disimpulkan telah terjadi masalah Heteroskedastisitas.

b. Jika pada grafif scatter plot, titik-titik menyebar di atas dan di bawah angka nol pada sumbu Y serta tidak membentuk pola tertentu yang teratur, misal bergelombang, melebar kemudian menyempit, maka dapat disimpulkan tidak terjadi masalah heteroskedastisitas (variance sama/ Homoskedastisitas) 


\subsection{Metoda Analisis}

Penelitian ini menggunakan metode estimasi Ordinary Least Square (OLS) untuk menguji hubungan antara Inflasi dan faktor yang mempengaruhinya dengan persamaan sebagai berikut :

INFLASI $=\alpha_{0}+\alpha_{1} \mathrm{JUB}+\alpha_{2}$ EKSPOR $+\alpha_{3} \mathrm{IMPOR}+\mu_{\mathrm{t}}$

Dimana

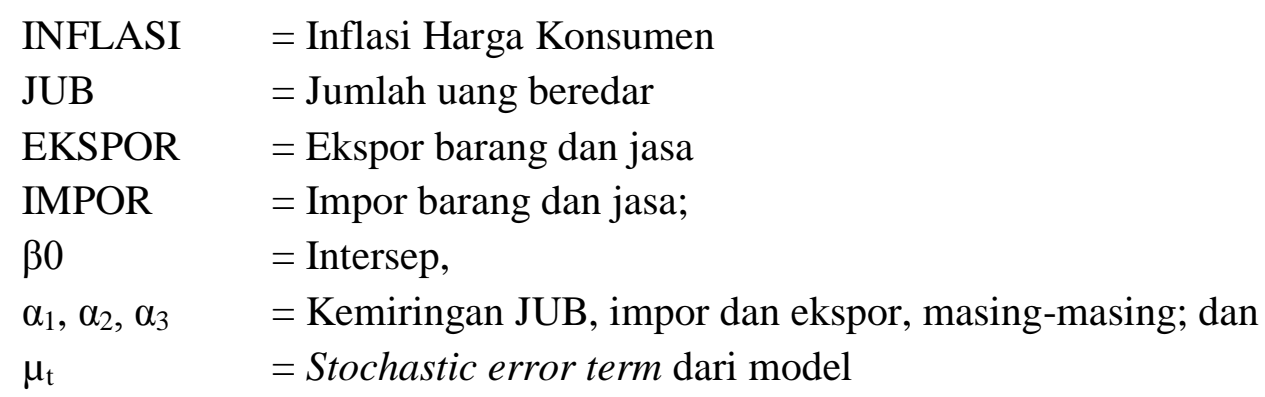

\subsection{Definisi operasional dan pengukuran variabel}

Inflasi : Merupakan Inflasiharga konsumen yang diukur dengan indeks harga konsumen yang mencerminkan perubahan persentase tahunan dalam biaya bagi konsumen rata-rata untuk memperoleh sekelompok barang dan jasa. Satuan dari variabel ini adalah persentase

JUB : Jumlah Uang Beredar adalah uang yang berada di tangan masyarakat yang terdiri dari $\mathrm{M}_{2}$. Satuan dari variabel ini adalah persentase.

Ekspor : Ekspor barang dan jasa merupakan nilai dari semua barang dan jasa lain yang dipasok ke seluruh dunia. Satuan dari variabel ini adalah persentase.

Impor : Impor barang dan jasa merupakan nilai dari semua barang dan jasa lain yang diterima dari berbagai belahan dunia. Satuan dari variabel ini adalah persentase.

\section{HASIL PENELITIAN DAN PEMBAHASAN}
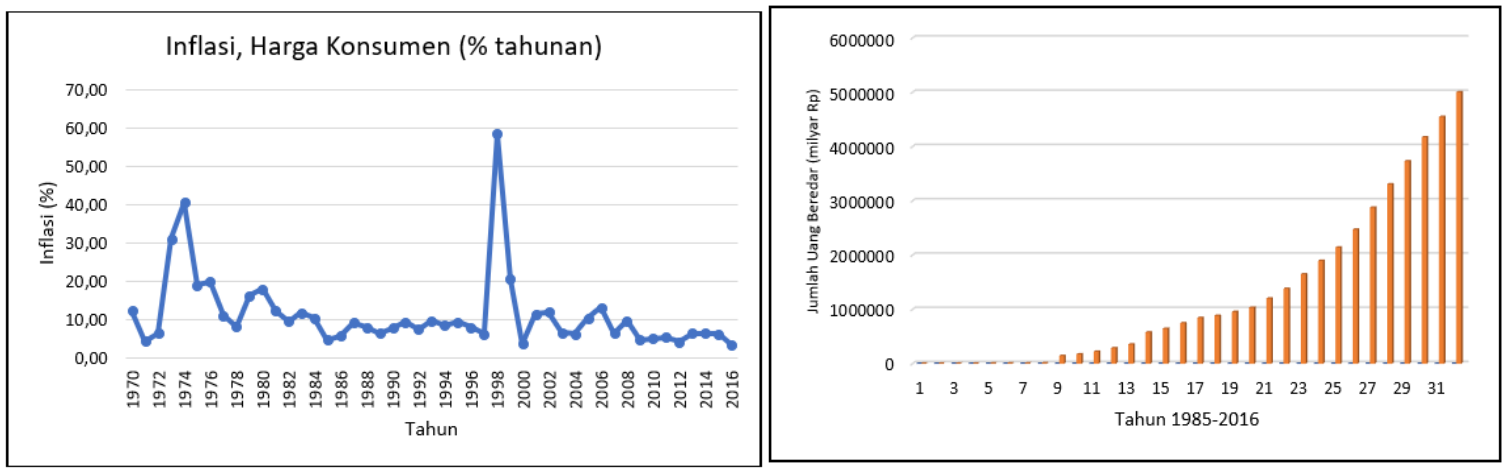

Gambar 1. Perkembangan Inflasi dan Jumlah uang beredar di Indonesia Tahun 1985-2016

Pada Gambar 1 dan 2 disajikan perkembangan variabel ekonomi yang menjadi variabel dalam penelitian ini. Perkembangan Inflasi terus berfluktuasi dan mulai stabil 
setelah tahun 2000 sedangkan jumlah uang beredar dari tahun 1985-2016 terus megalami pertumbuhan. Sementara perkembangan ekspor dan impor sejak tahun 1970- 2016, cenderung fluktuatif.

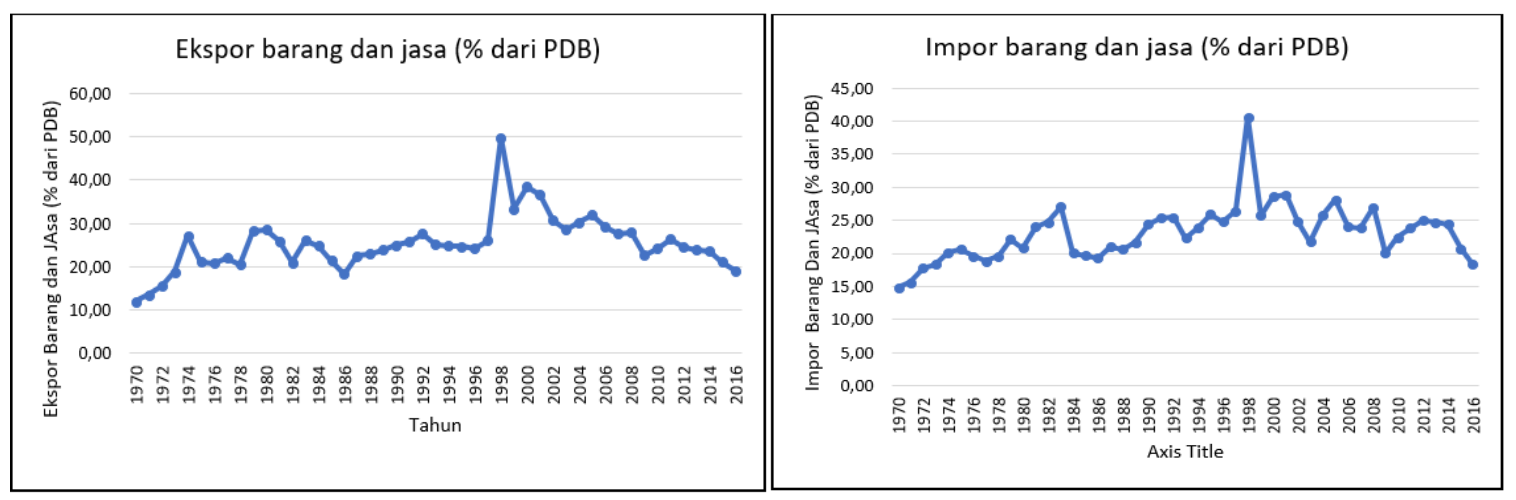

Gambar 2. Perkembangan Ekspor dan Impor Tahun 1970-2016

\subsection{Pengecekan Stasioneritas}

Hal penting yang harus diingat ketika menganalisis data time series adalah mengutamakan pengecekan stasioneritas datanya sebelum diproses lebih lanjut. Berikutnya adalah hasil uji stationer data penelitian:

Tabel 1. Hasil Pengujian Stasioner Pada Level

\begin{tabular}{lccc}
\hline Series & Prob. & Bandwidth & Obs \\
\hline EKSPOR & 0.0678 & 3.0 & 29 \\
\hline IMPOR & 0.0085 & 3.0 & 29 \\
\hline INFLASI & 0.0016 & 0.0 & 29 \\
\hline JUB & 0.9600 & 3.0 & 29 \\
\hline
\end{tabular}

Tabel 1 menyajikan hasil uji stasioner pada level. Hasil pengujian menunjukkan masih ada variabel yang tidak stasioner pada Level (nilai Prob. > 0,05), yaitu variabel Ekspor dengan nilai Probabilita 0,0678 dan variabel JUB dengan nilai probabilita 0,9600. Karena masih ada variabel yang belum stasioner maka semua variabel harus distasionerkan dengan 1st difference sehingga nilai Probability semua variabel berada di bawah 0,05 seperti terlihat pada Tabel 2 berikut ini.

Tabel 2. Hasil Pengujian Stasioner Pada 1st difference

\begin{tabular}{lccc}
\hline Series & Prob. & Bandwidth & Obs \\
\hline EKSPOR & 0.0000 & 0.0 & 28 \\
\hline IMPOR & 0.0000 & 0.0 & 28 \\
\hline INFLASI & 0.0001 & 27.0 & 28 \\
\hline JUB & 0.0059 & 4.0 & 28
\end{tabular}

Karena semua variabel sudah memiliki probability kurang dari 0,05, maka semua variabel sudah besifat stasioner. 


\subsection{Uji Normalitas}

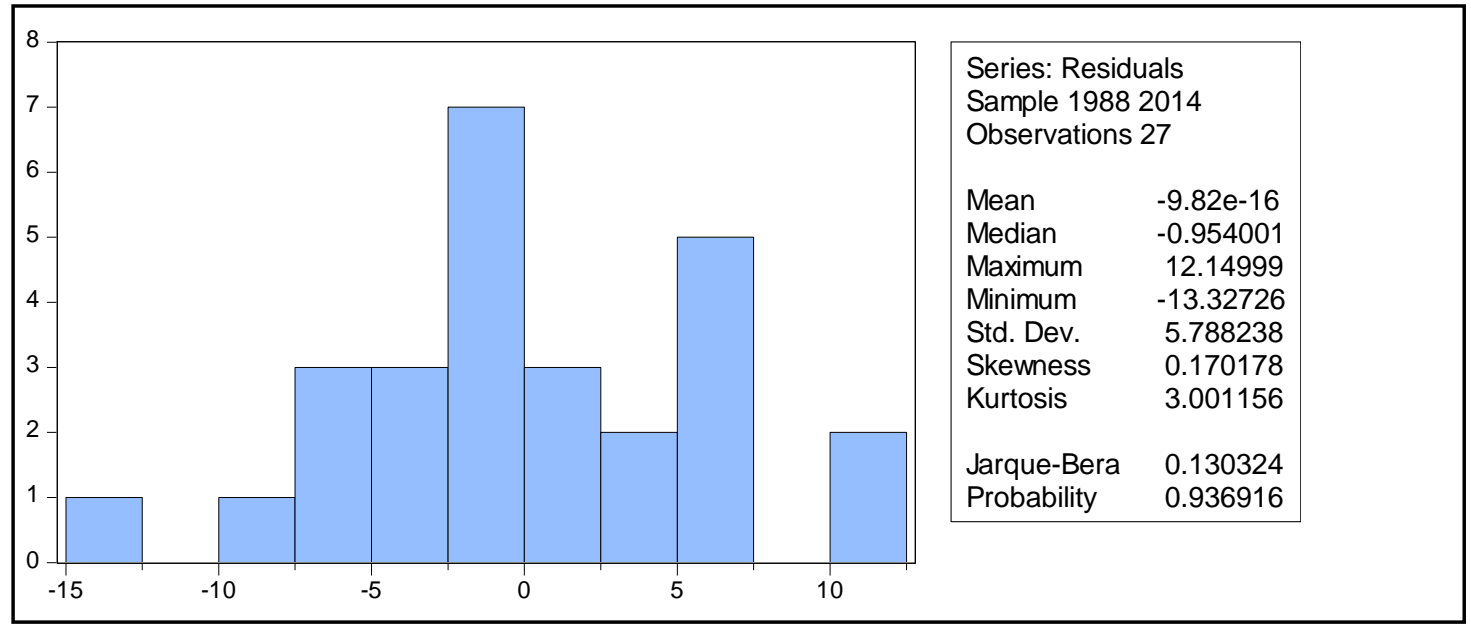

Gambar 3. Output: Probabilitas Jarque Bera Untuk Menguji Normalitas

Berdasarkan hasil uji normalitas nilai probabilitas Jarque Bera adalah 0,937 > 0,05). Dengan demikian dapat disimpulkan bahwa model regresi pada penelitian ini memenuhi asumsi normalitas.

\subsection{Uji Serial Korelasi}

Berdasarkan hasil analisis output pada Tabel 3 diperoleh nilai Obs probabilitas $F$ statistic 0,0151>0,05, maka dapat disimpulkan model regresi yang dipakai dalam penelitian ini bebas dari masalah serial korelasi diterima.

Tabel 3. Hasil Analisis Output

\begin{tabular}{llll}
\hline F-statistic & $\mathbf{4 . 5 0 7 4 2 7}$ & Prob. F(2,20) & $\mathbf{0 . 0 2 4 2}$ \\
\hline Obs*R-squared & 8.388843 & Prob. Chi-Square(2) & 0.0151 \\
\hline
\end{tabular}

\subsection{Uji Linearitas}

Berdasarkan hasil pengolahan data pada Tabel 4 diperoleh nilai probabilitas $F$ statistic $0,3691<0,05$, maka hipotesis yang menyatakan bahwa model linear diterima.

Tabel 4. Ramsey RESET Test

\begin{tabular}{lccc}
\hline & Value & df & Probability \\
\hline t-statistic & 0.915405 & 24 & 0.3691 \\
\hline F-statistic & 0.837965 & $(1,24)$ & 0.3691 \\
\hline Likelihood ratio & 0.995266 & 1 & 0.3185 \\
\hline
\end{tabular}

\subsection{Uji Heteroskedastisitas}

Berdasarkan hasil uji heteroskedastisitas pada Gambar 4 menunjukkan bahwa titik menyebar antara nilai prediksi variabel dengan residualnya secara acak, tidak membentuk suatu pola tertentu yang pasti, sehingga tidak terdapat masalah heteroskedastisitas pada model. 


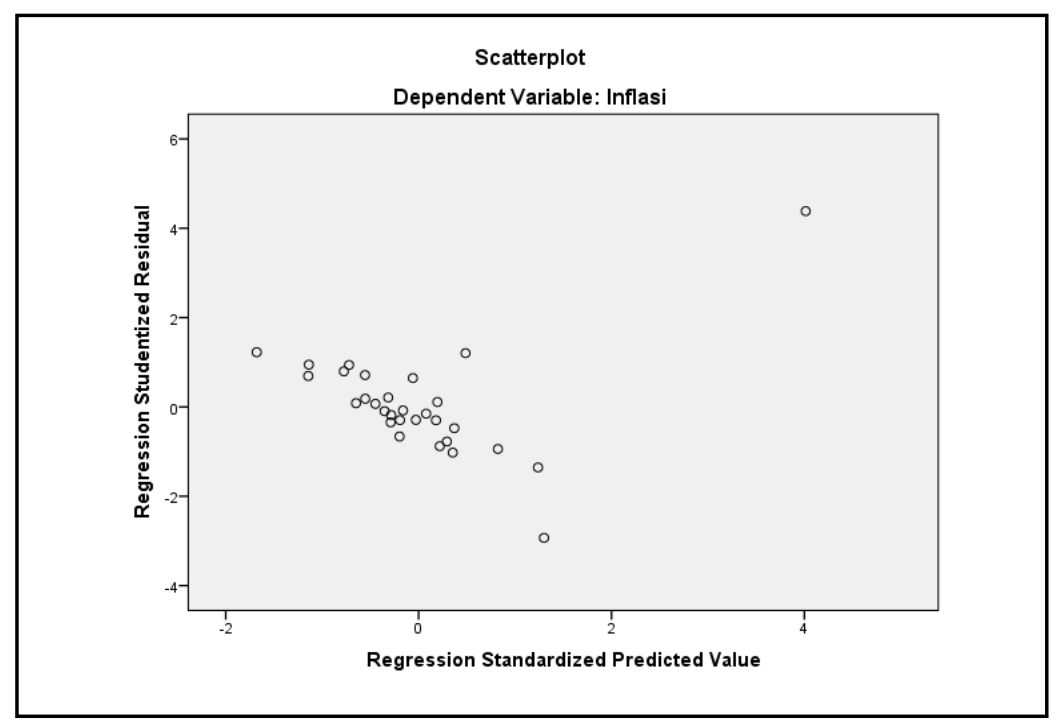

\section{Gambar 4. Hasil Pemeriksaan Asumsi Heteroskedastisitas}

\subsection{Kelayakan Model}

Uji keterandalan model atau uji kelayakan model atau yang lebih populer disebut sebagai uji F (uji simultan) merupakan tahapan awal mengidentifikasi model regresi yang diestimasi layak atau tidak. Karena mengikuti mengikuti distribusi F yang kriteria pengujiannya seperti One Way Anova. Apabila nilai prob. F hitung lebih kecil dari tingkat kesalahan/error $(\alpha=0,05)$ yang telah ditentukan, maka dapat dikatakan bahwa model regresi yang diestimasi layak, sedangkan apabila nilai prob. F hitung lebih besar dari tingkat kesalahan 0,05 maka dapat dikatakan bahwa model regresi yang diestimasi tidak layak.

Tabel 5. One Way Anova

\begin{tabular}{lllcc}
\hline Variable & Coefficient & Std. Error & t-Statistic & Prob. \\
\hline EKSPOR & 1.739243 & 0.600551 & 2.896077 & 0.0077 \\
\hline IMPOR & 0.057890 & 0.756929 & 0.076480 & 0.9396 \\
\hline JUB & $3.92 \mathrm{E}-05$ & $2.02 \mathrm{E}-05$ & 1.935770 & 0.0643 \\
\hline C & -1.122758 & 1.413795 & -0.794145 & 0.4346 \\
\hline R-squared & 0.743586 & Mean dependent var & -0.198265 & \\
\hline Adjusted R-squared & 0.712816 & S.D. dependent var & 12.91374 & \\
\hline S.E. of regression & 6.920412 & Akaike info criterion & 6.834270 & \\
\hline Sum squared resid & 1197.303 & Schwarz criterion & 7.022862 & \\
\hline Log likelihood & -95.09691 & Hannan-Quinn criter. & 6.893335 & \\
\hline F-statistic & 24.16619 & Durbin-Watson stat & 1.985819 & \\
\hline Prob(F-statistic) & 0.000000 & & & \\
\hline
\end{tabular}

Berdasarkan Tabel 5 diperoleh Nilai prob. F (Statistic) sebesar 0,000000 lebih kecil dari tingkat signifikansi 0,05 sehingga dapat disimpulkan bahwa model regresi yang diestimasi layak digunakan untuk menjelaskan pengaruh Jumlah uang beredar, Ekspor dan Impor terhadap variabel Inflasi di Indonesia. 


\subsection{Uji t (Uji Koefisien Regresi)}

Pada Tabel 5, nilai prob. $\mathrm{t}$ hitung lebih kecil dari tingkat kesalahan (alpha) 0,05 maka dapat dikatakan bahwa variabel bebas berpengaruh signifikan terhadap variabel terikatnya, sedangkan apabila nilai prob. $t$ hitung lebih besar dari tingkat kesalahan 0,05 maka dapat dikatakan bahwa variabel bebas tidak berpengaruh signifikan terhadap variabel terikatnya.

Berdasarkan Tabel 5, diperoleh Nilai prob. t hitung dari variabel bebas Ekspor sebesar 0,0077 yang lebih kecil dari 0,05 sehingga variabel ekspor berpengaruh signifikan terhadap variabel Inflasi pada alpha 5\% atau dengan kata lain, Ekspor berpengaruh signifikan terhadap Inflasi pada taraf keyakinan 95\%. Pengaruh variabel bebas Impor terhadap variabel terikat Inflasi, karena nilai prob. t hitung 0,9396 yang lebih besar dari 0,05 sehingga dapat dikatakan bahwa variabel bebas Impor berpengaruh tidak signifikan terhadap variabel terikat inplasi pada alpha 5\%. Nilai prob. $t$ hitung dari variabel jumlah uang beredar sebesar 0,0643 yang lebih kecil dari 0,10 sehingga jumlah uang beredar berpengaruh signifikan terhadap inflasi pada alpha $90 \%$.

\subsection{Koefisien Determinasi}

Koefisien determinasi menjelaskan variasi pengaruh variabel-variabel bebas terhadap variabel terikatnya. Nilai R - Square pada Tabel 6 besarnya 0,743586 menunjukkan bahwa proporsi pengaruh JUB, Eksor dan Impor terhadap variabel Inflasi sebesar 74,35\%. Artinya, pengaruh JUB, Eksor dan Impor terhadap variabel Inflasi sebesar 74,35\% sedangkan sisanya 25,65\% (100\% - 74,35\%) dipengaruhi oleh variabel lain yang tidak dibahan dalam penelitian ini.

Berdasarkan Tabel 5 diperoleh persamaan regresi dalam penelitian ini sebagai berikut :

\section{Inflasi $=-1.123+1.739$ Ekspor -0.0579 Impor $+3.920 \mathrm{JUB}$}

\subsection{Pengaruh Jumlah Uang Beredar Terhadap Inflasi}

Menurut Greenidge \& Dacosta, (2009), inflasi telah menjadi isu topikal sejak awal 1970-an ketika harga minyak melambung tinggi. Sejak saat itu, mengendalikan tingkat inflasi telah menjadi prioritas utama banyak negara terutama yang memiliki ekonomi terbuka kecil Greenidge \& Dacosta, (2009). Indonesia sebagai negara yang memiliki ekonomi terbuka tentu tidak terlepas dari pengaruh ekonomi gelobal yang selalu ikut mempengaruhi variabel ekonomi dalam negeri Indonesia.

Koefisien Jumlah uang beredar bertanda positif dan secara statistik signifikan pada tingkat signifikansi 5 persen. Temuan ini sesuai dengan teori dari monetaris yang mengatakan kebijakan moneter yang ekspansif (kebijakan uang longggar) dapat meningkatkan inflasi (Romer, 1993). Ini menunjukkan bahwa jumlah uang beredar merupakan faktor penting dari proses inflasi di Indonesia. Oleh karena itu dalam mengambil kebijakan moneter terutama kebijakan moneter ekspnsif perlu berhati-hati 
dan berkoordinasi dengan otoritas pengambil kebijakan ekonomi yang lain, sehinnga tujuan kebijakan moneter untuk mendorong pertumbuhan ekonomi dan kesejahraan masyarakat bisa di capai, tanpa harus diikuti dengan kenaikan harga yang teralu tinggi.

Temuan impiris penelitian ini sesuai dengan hasil penelitian Greenidge \& Dacosta, (2009) yang menyatakan bahwa dalam jangka panjang, penambahan jumlah uang beredar memiliki pengaruh yang signifikan terhadap inflasi di Nigeria. Berikutnya Bozkurt, (2014) menyatakan bahwa penambahan jumlah uang beredar merupakan penentu utama inflasi dalam jangka panjang di Turki. Selanjutnya Inam, (2014) yang menyatakan ada hubungan linear jangka panjang antara suplai uang dan inflasi di Nigeria.

\subsection{Pengaruh Ekspor Terhadap Inflasi}

Inflasi pada ekonomi terbuka juga dipengaruhi oleh situasi perdagangan internasional yaitu kondisi impor dan ekspor. Ekspor mempengaruhi persediaan produk yang tersedia bagi konsumen domestik, dan karenanya mempengaruhi harga. Artinya, perdagangan internasional berfungsi seperti pintu terbuka, sehingga tekanan harga didalam negeri bisa dikurani oleh arus produk masuk kenegara tersebut. Ketika permintaan melebihi tingkat output domestik maka ketidaksesuaian antara permintaan dan kondisi pasokan mengarah ke kondisi inflasi. Menanggapi kelebihan permintaan ini dapat memanfaatkan kebijakan impor. Di sisi lain, ketika permintaan di bawah tingkat output domestik, inflasi akan mulai berkurang. Selain itu, kelebihan output dapat ditangani dengan mengekspor ke negara lain.

Koefisien keterbukaan perdagangan memiliki tanda positif dan signifikan secara statistik pada tingkat signifikansi 5 persen. Ini berarti pemerintah perlu memperhatikan kebutuhan barang dan jasa dalam negeri terlebih dahulu sebelum melakukan ekspor. oleh karena itu dalam mengambil kebijakan tentang ekspor perlu berhati-hati dengan memperhatikan kebutuhan masyarakat dalam negeri tertebih dahulu baru kemudian melakukan ekspor. Temuan ini didukung oleh hasil empiris Lim \& Papi, (1997) harga ekspor dan harga impor memiliki pengaruh positif pada tingkat harga domestik di mana sebagai nilai tukar berlaku terbalik pada tingkat harga domestik di Turki.

\subsection{Pengaruh Impor Terhadap Inflasi}

Inflasi pada ekonomi terbuka juga dipengaruhi oleh situasi perdagangan internasional yaitu kondisi impor dan ekspor. Menurut Dexter et al., (2002), Ketersediaan impor dapat mempengaruhi inflasi domestik secara langsung melalui harga impordan secara tidak langsung melalui persaingan dengan barang dan jasa domestik. Ketika permintaan dalam negeri melebihi tingkat output domestik maka ketidaksesuaian antara permintaan dan kondisi pasokan mengarah ke kondisi inflasi. Menanggapi negara permintaan berlebih ini dapat memanfaatkan kebijakan impor. Di sisi lain, ketika permintaan di bawah tingkat output domestik, inflasi akan mulai terkikis. Selain itu, kelebihan output dapat ditangani dengan mengekspor ke negara lain. Tetapi situasi impor 
dan ekspor ini juga berkontribusi pada asal-usul inflasi. Biasanya, kenaikan impor akan menyebabkan depresiasi dalam nilai tukar. Ini cenderung meningkatkan tekanan inflasi melalui impor mahal. Selain itu, ketika suatu negara mengimpor bahan mentah maka depresiasi mata uang lokal atau apresiasi mata uang asing membuat impor mahal dan kemudian biaya produksi untuk barang meningkat karena kenaikan harga mentah.

Hasil penelitian ini menemukan bahwa impor berpengaruh positif terhadap inplasi, artinya semakin tinggi impor maka tingkat inflasi akan semakin rendah. Ogbokor, (2004) impor sangat berpengaruh terhadap inflasi di Namibia. Kemudian Islam, (2013) ada korelasi signifikan tapi kecil antara impor dengan inflasi. Ulke \& Ergun, (2012) menyatakan bahwa ada hubungan jangka panjang dan dinamis antara inflasi dan impor di Turki serta Abidemi et al., (2010) mengungkapkan bahwa antara variabel impor memiliki hubungan positif dengan inflasi di Nigeria.

\section{SIMPULAN}

Karakteristik Inflasi di setiap negara berbeda, termasuk faktor-faktor yang mempengaruhinya. Penelitian ini menguji pengaruh jumlah uang beredar, ekspor dan impor terhadap Inflasi di Indonesia menggunakan data tahun 1981-2016. Penelitian ini menemukan (1) Jumlah uang beredar berpengaruh positif dan signifikan terhadap inflasi di Indonesia artinya bila terjadi penambahan jumlah uang beredar akan berdampak positif terhadap kenaikan harga barang dan jasa (2) Ekspor berpengaruh positif dan signifikan terhadap inflasi di Indonesia. Ekspor mempengaruhi persediaan produk yang tersedia bagi konsumen domestik sehingga dapat mempengaruhi harga di dalam negeri, (3) Impor berpengaruh positif namun tidak signifikan mempengaruhi inflasi di Indonesia.

Penelitian ini berhasil membuktikan penambahan jumlah uang beredar berpengaruh positif terhadap inflasi, artinya bila penambahan jumlah uang dilakukan akan berdampak pada peningkatan inflasi. Oleh karena itu bagi pengambil kebijakan terutama kebijakan moneter yang bersifat ekspansif (kebijakan uang loggar) perlu berhati-hati dalam menambah jumlah uang beredar, karena akan berdampak pada peningkatan inflasi. Oleh karena itu diperlukan koordinasi dengan otoritas pengambil kebijakan lain agar tidak terjadi tumpang tindih sehingga penambahan jumlah uang beredar tidak terlalu berdampak terhadap kenaikan inflasi. Penelitian ini juga menemukan ekspor berpengaruh signifikan pada inflasi sehingga pengambil kebijakan tentang ekspor harus memperhatikan pasar kebutuhan pasar dalam negeri dulu baru melakukan ekspor supaya kesetabilan harga di dalam negeri bisa terjaga sehingga tidak merugikan masyarakat. Hubungan positif yang terjadi antara ekspor dan inflasi juga memiliki implikasi luas bagi pembuat kebijakan di Indonesia. Karena secara khusus implikasi kebijakan perdagangan yang berorientasi ke luar akan meningkatkan inflasi di Indonesia. Sedangkan impor tidak berpengaruh terhadap inflasi di Indonesia tahun 1981-2016.

Penelitian ini dilakukan di Indonesia, sehingga informasi dan hasil Penelitian ini mungkin tidak cocok untuk negara lain, karena implikasi kebijakan dan tantangan yang 
berbeda. Penelitian ini hanya menggunakan tiga variabel independent yaitu jumlah uang beredar, ekspor, impor dan inflasi yang mempengaruhi inflasi, padahal mungkin masih ada variabel lain yang mempengaruhi inflasi seperti pengngguran, pertumbuhan ekonomi, suku bunga dan nilai kurs yang tidak dipertimbangkan dalam penelitian ini. Variabel penting ini tidak masuk karena keterbatasan data yang peneliti dapatkan. Semua ini merupakan kelemahan dari penelitian ini.

Oleh karena itu, penelitian ke depan sebaiknya mempelajari fenomena inflasi di berbagai negara dengan membagi negara-negara ke dalam kelompok negara terbelakang, negara berkembang, dan negara maju. Dengan demikian peneliti dapat mempelajari dampak ketidaksetaraan dalam ekonomi yang menyebabkan perbedaan yang mempengaruhi tingkat inflasi di negara tersebut. Di sisi lain, peneliti kedepan juga dapat memasukkan variabel ekonomi makro lainnya seperti pengngguran, pertumbuhan ekonomi, suku bunga dan nilai kurs yang dapat mempengaruhi inflasi agar diperoleh hasil penelitian yang lebih akurat.

\section{DAFTAR PUSTAKA}

Abidemi, O. I., Maliq, A. A. A., \& Ago-Iwoye. (2010). Analysis of Inlation and its Determinants in Nigeria. Journal of Social Sciences, 7(2), 97-100.

Akinbobola, T. O. (2012). The dynamics of money supply, exchange rate and inflation in Nigeria. Journal of Applied Finance \& Banking, 2(4), 117-141. https://doi.org/17926599

Arif, K. M., \& Ali, M. M. (2012). Determinants of Inflation in Bangladesh: An Empirical Investigation. Journal of Economic and Sustainable Development, 3(12), 9-17. https://doi.org/10.1111/j.1813-6982.2011.01273.x

Bashir, F., Nawaz, S., Yasin, K., Khursheed, U., Khan, \& Qureshi, M. J. (2011). Determinants of Inflation in Pakistan: an Econometric Analysis Using Johansen CoIntegration Approach. Australian Journal of Business and Management Research, 1(5), 71-82.

Bello, M. Z., \& Saulawa, M. A. (2013). Reationship between Inflation, Money Supply, Interest Rate and Income Growth ( Rgdp ) in Nigeria 1980-2010. An Empirical Investigation . Journal of Economics and Sustainable Development, 4(8), 7-13.

Bozkurt, C. (2014). Money, Inflation and Growth Relationship: The Turkish Case. International Journal of Economics and Financial Issues, 4(2), 309-322.

Dexter, A. S., Levi, M. D., \& Nault, B. R. (2005). International Trade and the Connection Between Excess Demand and Inflation by. Review of International Economics, 13(4), 699-708. https://doi.org/https://doi.org/10.1111/j.14679396.2005.00532.x

Greenidge, K., \& Dacosta, D. (2009). Determinants of Inflation in Selected Caribbean Countries. Business, Finance \& Economics in Emerging Economis, 4(2), 371-397.

Inam, U. S. (2014). An Empirical Investigation of the Relationship between Money Supply and Inflation in Nigeria (1970-2011). International Journal of Humanities Social Sciences and Education (IJHSSE), 1(12), 65-76. 
Islam, M. A. (2013). Impact of Inflation on Import: An Empirical Study. International Journal of Economics, Finance and Management Sciences, 1(6), 299. https://doi.org/10.11648/j.ijefm.20130106.16

Jaradat, M. (2013). An Econometric Analysis of the Determinants of Inflation. The Internatioanl Journal of Social Science, 11(15), 29-36.

Koyuncu, F. T. (2014). Causality Network between Budget Deficit, Money Supply and Inflation: An Application to Turkey. International Journal of Business and Social Science, 5(101), 225-235.

Lim, C. H., \& Papi, L. (1997). An Economic Analysis of the Determinants of Inflation in Turkey. IMF Working Paper.

Ofori, C. F., Danquah, B. A., \& Zhang, X. (2017). The Impact of Money Supply on Inflation, A Case of Ghana. Imperial Journal of Interdisciplinary Research (IIJR), 3(1), 2312-2318.

Ogbokor, C. A. (2004). Study, Inpacts of Inflastion on Namibia Growth: An Empirical. Journal of Applied Sciences, 4(4), 644-648.

Phillips, A. W. (1958). The Relation Between Unemployment and the Rate of Change of Money Wage Rates in the United Kingdom , 1861-19571. Economica, 25(100), 283-299.

Ramzan, Fatima, K., \& ZareenYousaf. (2013). An Analysis of The Relationship between Inflation and Trade Openness. Interdisciplinary Journal of Contemporary Research in Business, 5(3), 215-229.

Rehman, F. U., \& Khan, D. (2015). The Determinants of Food Price Inflation in Pakistan: An Econometric Analysis. Advances in Economics and Business, 3(12), 571-576. https://doi.org/10.13189/aeb.2015.031205

Romer, D. (1993). Openess and inflation: Theory and evidence. The Quarterly Journal of Economics, CVIII(4), 869-903.

Shah, M. A. A., Aleem, M., \& Nousheen, A. (2014). Statistical Analysis of the Factors Affecting Inflation in Pakistan. Middle-East Journal of Scientific Research, 21(1), 181-189. https://doi.org/10.5829/idosi.mejsr.2014.21.01.21134

Tafti, F. (2012). Determinants of inflation in Islamic Republic of Iran. Journal of Business and Social Science, 3(6), 197-203.

Tang, C. F., \& Lein, H. H. (2007). Is the Phillips Curve Stable for Malaysia? New Empirical Evidence. Malaysian Journal of Economic Studies, 44(2), 95-105.

Ulke, V., \& Ergun, U. (2012). Econometric Analysis of Import and Inflation Relationship in Turkey between 1995 and 2010. Journal of Economic and Social Studies, 1(2), 69-86. https://doi.org/10.2139/ssrn.2158343

Venkadasalam, S. (2015). The Determinant of Consumer Price Index in Malaysia. Journal of Economics, Business and Management, 3(12). https://doi.org/10.7763/JOEBM.2015.V3.344 